\title{
Some Geological Aspects of Recent Research on Coal*
}

\author{
By Prof. H. G. A. Hickling
}

I BELIEVE that coal is not only in itself worthy 1 of more attention at the hands of the geologist than it has been generally accorded, but also is likely to repay that attention by shedding light on some of the major problems of geological science. Later, I shall revert to the conception of coal as a metamorphic rock. The idea is ancient, but the data necessary for its establishment and more precise definition have been lacking. Perhaps they are now to hand. If that be so, we have in this familiar rock an indicator of crustal conditions far more delicate than any of the index minerals of the metamorphic petrologist; so delicate indeed, that should it come within range of even the lowest grade of metamorphism, as usually understood, it is completely shrivelled up and leaves only a trace of graphite as witness of its former self.

\section{Structure of Coal}

So far back as 1831, Henry Witham had prepared microscopic sections in which he had seen plant structure, and in January 1833, a paper was read before the Geological Society of London, by William Hutton, based on the examination of a considerable collection of thin sections. It was, unfortunately, published in brief abstract only, but the original manuscript, at present in my possession, shows that he had observed most of the features which were noted by later observers until very recent times. This was the first serious attempt to determine the structures of the different kinds of coal, and little advance was made in this matter for more than half a century.

The modern period of coal petrology is clearly the offspring of the palæobotanical research on petrified coal which culminated at the close of the nineteenth century. This work gave us a precise knowledge of the structure of the plants which formed the Carboniferous coals, and a clear picture of the condition of some of the coal peats at the time of their deposition. It was inevitable that this should be followed by more determined attempts to see these structures in the coal itself, and was equally natural that such attempts should be made quite independently by a number of workers.

\section{The 'Uniform Brown Substance'}

Before the time of Witham and Hutton, coal was often regarded as a deposit from 'solution' in

* From the presidential address to Section C (Geology) of the British Association, delivered at Norwich on September 6. water-as a kind of vegetable 'extract', which might consequently be expected to possess a distinctive composition, independently of the materials from which it was derived. The earlier microscopic observations at once limited this idea by demonstrating the presence of plant remains which retained their organised structure; but Hutton directed attention especially to a 'uniform brown substance' as the dominating constituent of the commoner types of coal. This clearly appealed to many observers as the essential feature, and many references to the 'coal substance' seem to be more or less clearly identified with it. The foremost question in coal petrology has been, in fact, the nature of this brown substance-in particular, as to whether it is, in more modern phrase, a colloidal precipitate, or whether it represents actual fragments of plant material. Since it forms probably quite 75 per cent of all our common coal, this question is of the first importance.

All recent workers have directed attention largely to this dominating material. E. C. Jeffrey named it 'lignitoid material'. He regards it as representing pieces of plant tissue, largely woody, in which all trace of the original organisation has been destroyed by decay. Thiessen differed from Jeffrey chiefly in his belief that the structure of the original plant material is rarely quite obliterated, and that it can nearly always be detected if the sections and the microscopic technique be suffciently good. He named the material 'anthraxylon'.

In 1919, Dr. Marie Stopes essayed a classification of the types of coal substance which can be distinguished by eye in an ordinary bituminous seam. While earlier writers had usually been content to describe the coal as divisible into 'bright' and 'dull' layers, together with occasional bands of 'mineral charcoal' or 'mother of coal', she directed attention to the additional fact that the 'bright' coal might be separated into two portions. The general mass of the bright substance has a just perceptible fine lamination which gives it a silky sheen; but interbanded with it are many thin layers which at once strike the eye by the mirror-like reflection from their perfect cleavage surfaces. She applied distinctive names to the different types of laminæ, adopting the French fusain to replace the questionable English term 'mineral charcoal', and devising corresponding terms for the other types of coal: durain for the true dull bands ; clarain for the ordinary silky 
bright coal; and vitrain for the brilliant glassylooking substance.

Turning to the microscopic characters of these types of coal, she observed that the clarain bands were mainly composed of this uniform brown substance, finely interspersed with other ingredients, and often showing its original plant structure; while vitrain consisted entirely of similar material, free from admixture with other substances, but seemed to show no trace of structure. The development of technique during the past decade has shown, however, that this latter distinction was apparent only. In direct proportion as the methods of preparing thin sections or of etching coal surfaces have been improved, an ever-increasing proportion of the 'uniform brown substance' of the bright coal has been shown to retain the structure of the plants of which it is composed.

\section{Nature of the 'Uniform Brown Substance'}

Thus the 'uniform brown substance' for the most part, at least, represents portions of plant tissue with their organised structures exquisitely preserved; and there are those who regard it as made up entirely of such fragments, each of which now consists only of the remains of the organic substance of which that particular plant fragment was originally composed. The alternative view is that a large part of the substance of the original vegetation was reduced by early decay to the condition of a true fluid, some of which was absorbed into those plant fragments which retained their organisation, while other portions of the fluid may have solidified as a truly structureless gel, and acted as a cement to the whole mass. Whatever may be the amount of truth in this latter hypothesis - and there is considerable evidence that material which must have been absorbed in a fluid condition is present in some cases-it is absolutely unquestionable that the plant remains which now form this translucent coal substance have been rendered jelly-like, whether by their own decay or by absorption of extraneous material. In nearly all cases, cell-walls which were clearly rigid have been flattened and folded without rupture. Often the entire tissue has been contorted into the most fantastic forms but still remains unbroken.

In any case there is little reason for supposing that the essential nature of this substance is very different whether the plant-structure be discernible or not; all our evidence points to a remarkable general uniformity. Its ash-content is always found to be amazingly low. Not only is it a mere fraction of that present in the rest of the coal substance, but it is much below that in any average aggregate of modern plant materials. There is no reason for supposing that the vegeta- tion of the coal-forests was abnormal in its content of inorganic matter, so we must presume either that the inorganic content of this part of the coal has been reduced, by leaching out, or that there has been a very large addition of pure organic substance. Further, this material shows extremely little variation in its organic composition, as compared with the other constituents of the coal While the hydrogen content, for example, in the different ingredients of a single block of bituminous coal may be found to range from $3 \frac{1}{2}$ to 8 per cent, the variation among samples of vitrain from the same block will rarely exceed a twentieth of that amount. It is because most coals consist mainly of this substance that they differ so little from one another. Prof. Wheeler and his colleagues have shown that it is mainly composed of ulmin compounds.

In the absence, hitherto, of any generally accepted name to denote this most important of all coal constituents, I propose for the present to adopt the term recently suggested by Dr. Stopes and call it vitrinite.

\section{Other COMPonents OF COAL}

We must now take stock of the other materials which go to the make-up of an ordinary coal seam. Though they are subsidiary in amount to the vitrinite in most portions of the seam, it is the character and varying quantity of these other materials which primarily differentiate the quality of the coals.

Most conspicuous and familiar is the 'mineral charcoal' or fusain. This illustrates at once the fact that in some cases the mode of preservation of the plant-substance may be of greater import than its original nature. The fusain is usually woody tissue, clearly identical originally with much of that which has been converted into vitrinite. But how different in its present form ! Devoid of any organic substance in its cell-cavities ; every cell-wall so brittle as to break at a touch; always extremely low in its content of hydrogen and oxygen, and correspondingly high in carbon. Physically and chemically it stands in the strongest possible contrast. On account of its porous nature, it has commonly formed the receptacle for much of the mineral matter which has been deposited from solution in the coal, and is consequently a great carrier of ash. Quite moderate variation in the amount of fusain in the coal has important effects on its utility for various purposes.

The next group of coal components may for the purpose of this review be designated the 'highhydrogen' group - the outer coatings of stems, leaves and spores which are characterised by an accumulation of waxes, fats, resins and allied substances. They differ so strikingly in chemical 
properties from the rest of the coal that by the roughest chemical treatment the remainder of the coal can be broken down while the spore-coats and cuticles are left little altered. They are then seen under the microscope to differ in structure little, if at all, from their condition in a living plant. Their obvious relative indestructibility has resulted in their accumulation in the coal in quantities much in excess of their natural proportion-in extreme cases, even to the total exclusion of other materials.

Associated with the cuticles and spores in respect of chemical peculiarities and durability, but differing somewhat in the manner of distribution in the coal, are the resinous secretions of the plants. Since the resins were originally contained in the wood or bark, they are found largely in the vitrinite of the coal. On the other hand, they are often found in local aggregations among the more disintegrated plant debris, in such a manner as to suggest that the aggregates may represent the resinous content of a tissue which has, for the rest, been almost entirely destroyed.

There is one other distinctive ingredient in most ordinary coal seams, characterised by its minute state of fragmentation. It forms a kind of paste made up of particles of 1 or 2 microns or less in diameter. Obviously it represents quite a distinct stage in the degradation of the plant material; and there is some indication that it has distinctive chemical peculiarities. It is of very dense colour, and is consequently opaque except in the thinnest sections. It is essentially characteristic of the dull coals. So far it lacks a generally recognised title and bas been merely described as the 'residuum'. Dr. Stopes would christen it 'micronite'.

\section{'SAPRopelic Coals'}

The foregoing account of the components of coal deals with those to be found in our normal bituminous coals of Carboniferous age. So far as my knowledge extends, the account does not require material modification in reference to the coals or lignites of other ages. But there are other types of coal, particularly the cannels and bogheads, which have a widely different structure and at least one very different component material ; namely, the microscopic oil-bearing algæ. In the last few years these organisms have been carefully re-examined by Zalessky, by Thiessen, by $P$. Bertrand, and by my own colleague Dr. Temperley, who have not only demonstrated their structure in greater detail, but also have established their essential similarity (and possible identity) with the living oil-alga Botryococcus braunii. This constituent of the cannels affords the most striking of all examples of the effect of original materials on the composition of the coals. As the algal content increases, so the percentage of hydrogen in the coal rises, from about 6.0 per cent in those without algæ up to more than 12 per cent in the purest algal bogheads.

(To be continued.)

\section{Birkbeck College}

\section{Past, Present and Future}

$\mathrm{T}$ HE successful inauguration of the appeal for the rebuilding of Birkbeck College, originally the London Mechanics Institution (see NATURE, Nov. 16, p. 787), will be welcomed universally by students of science. The College, established at a meeting of 'mechanics' held in the Crown and Anchor Tavern in the Strand on December 2, 1823, had as its original purpose to provide scientific education for the skilled craftsmen who were the aristocracy of the Industrial Revolution. That the objective was education and not mere technical training is proved by the motto of the Mechanics Institutes established throughout the country: "To make a man a better mechanic we must make the mechanic a better man".

In the early days, as Mr. Ramsay MacDonald, a former student of the College, has said, their science was simple and stimulating. "Its revela- tions were both startling and fresh ; the controversies it roused were popular and the prospects it opened were inspiring." The opposition encountered by Birkbeck was essentially opposition to scientific training. "What is wanted," said Bell's Weekly Messenger, "is practical mechanics-instruction in trades ... Science, in the very nature of things, must be confined to a few"; and the St. James' Chronicle asserted that " $\mathrm{a}$ scheme more completely adapted for the destruction of this empire could not have been invented by the author of evil him. self. . .". Carlyle, in "Sartor Resartus", denounced its students as "professed Enemies of Wonder", cackling "like true Old-Roman geese and goslings round their Capitol, on any alarm, or on none" ; as illuminated sceptics guiding people with rattle and lantern when the sun is shining. He resented "that progress of Science which is to destroy mystery". 